Utah State University

DigitalCommons@USU

Co

Bee Lab

$10-1-1918$

\title{
A Group of American Halictine Bees Simulating the Old-World Genus Nomioides
}

T. D. A. Cockerell

University of Colorodo

Follow this and additional works at: https://digitalcommons.usu.edu/bee_lab_co

Part of the Entomology Commons

\section{Recommended Citation}

Cockerell, T. D. A., "A Group of American Halictine Bees Simulating the Old-World Genus Nomioides" (1918). Co. Paper 598.

https://digitalcommons.usu.edu/bee_lab_co/598

This Article is brought to you for free and open access by the Bee Lab at DigitalCommons@USU. It has been accepted for inclusion in Co by an authorized administrator of DigitalCommons@USU. For more information, please contact digitalcommons@usu.edu.

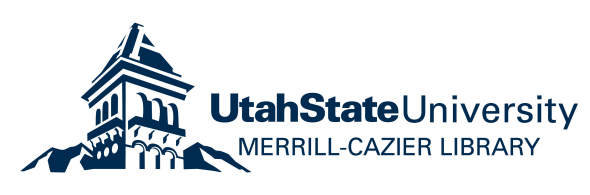


sides of face shining; inner orbits concave but not abruptly emarginate; scape long, black; flagellum dark above and ferruginous beneath; mesothorax dull and granular, with fine, very short, pale pruinose pubescence; tubercles yellow; tegulæ light fulvous; wings hyaline, nervures fuscous, outer nervures not weakened; first recurrent nervure joining extreme apex of second submarginal cell; area of metathorax large, microscopically reticulate, not plicate; legs pale yellowish or fulvous, the middle and hind tibiæ and tarsi fuscous, the middle tibiæ pale in front; hind spur with three very long spines; abdomen broad, smooth and shining, reddish fuscous and fulvous marked with lemon yellow; first segment broadly yellow basálly and at sides except apically, where it is dark brown, but otherwise the segment is pale fulvous; second and third segments with a broad, yellow basal band, widest sublaterally, the segments otherwise fulvous in middle and dark brown laterally; fourth and fifth segments reddish-fuscous, with basal yellow bands; venter pale yellow, with the last three segments fuscous.

Porto Bello, Panama, March 13, 1911. (Aug. Busck), U. S. Nat. Museum. Nearest to the Brazilian H. callichroma (Ckll.), but with entire yellow bands on abdomen. The structure of the metathoracic enclosure is quite the same, with fine reticulations, the lines mostly transverse. Of the other species of the group, I possess $H$. ephelix Vach., from Marcapata, Peru; H. phacodes Vach., from Mapiri, Bolivia; and a cotype of $H$. maculiventris (Crawford), described under Augochlora. Crawford's species seems doubtfully distinct from $H$. trinax Vach., but I have no authentic material of the latter. Crawford and I, describing species of this group, have referred them to Augochlora. Vachal referred all the species to Halictus, but he included Augochlora in Halictus. Schrottky in 1910 placed the species in his genus Nescorynura. They are certainly not genuine Augochlora, nor do they agree well with typical Nescorynura or Halictus. They may be considered a distinct subgenus of Halictus, or even a separate genus. I do not propose a name, because it is possible that Ctenocarynura Schrottky (Deutsch. Ent. Zeit., 1914) is applicable. I have not been able to procure Schrottky's description, and there is no reference to the genus in the Zoological Record. 


\section{RECENT CANADIAN PUBLICATIONS.}

Under this heading we propose to present notices from time to time of entomological publications by writers residing in Canada, or such as appear in Canadian periodicals, whether by Canadians or not. Exceptions will be made in the case of papers published in the Annual Reports of the Entomological Society of Ontario and the present journal. Short articles or those of a popular character will, as a rule, be merely listed.

Authors will greatly assist the Editor by sending him copies of their publications for notice in this section.

The following papers were all published during the present year: .

Proceedings of the Entomological Society of Nova Scotia for 1917. No. 3. Truro, January, 1918. Pp. 1-96.

This excellent report gives ample evidence of the vigorous condition of the youngest branch of our Society, and is a most creditable production. It contains no less than sixteen papers by ten contributors, dealing with a variety of subjects, both economic and faunistic, and these are illustrated by 15 plates, most of them half-tones of fine quality.

The following papers are mainly of economic interest:

Work of the Dominion Entomological Laboratory in Nova Scotia. By G. E. Sanders. An outline of the results of experiments testing the effects of different combinations of insecticides and fungicides in apple spraying.

Notes on the Yellow Leaf Hopper of the Birch (Oncopsis sobrius Walk.). By W. H. Brittain. The life-history is given in detail and is illustrated by two plates, showing all the stages, and the hymenopterous parasite, Polynema striaticorne Gir.

Miscellaneous Notes on the Apple Maggot. By. W. H. Brittain.

The Zebra Caterpillar. By H. G. Payne.

The Fall Cankerworm. By H. G. Payne.

The Rusty Tussock Moth. By H. G. Payne.

The White-marked Tussock Moth. By H. G. Payne.

Detailed life-histories of these four species are given, based on original data. They are illustrated by 5 excellent photographic plates.

October, 1918 